\title{
Deixis And Its Context Used In “Girl In Pieces” Novel By Kathleen Glasglow
}

\author{
Ary Iswanto Wibowo, Nida Nailufar \\ ${ }^{1}$ STIBA Nusa Mandiri, Jakarta \\ arysof123@gmail.com \\ ${ }^{2}$ Akademi Bahasa Asing BSI Jakarta \\ nidanailufar@gmail.com
}

\author{
Cara Sitasi : \\ Wibowo, A. I., \& Naulfar, N. (2018). Deixis And Its Context Used In “Girl In Pieces” Novel By Kathleen \\ Glasglow. Wanastra, 10(2), 73-84.
}

\begin{abstract}
Deixis is an interesting topic in pragmatic. Deixis is a word that represents something else in utterance. It could be referred to a person, to place, and to time. The reason of choosing deixis is because the languages in the novel often use pragmatic language. The writers used descriptive qualitative method to analyse deixis used in Girl in Pieces novel by Kathleen Glasglow. The procedures are collecting data, processing data, and analysis data. The result of this research indicated that there are three types of deixis used in the novel, person deixis, spatial deixis, and temporal deixis. Person deixis consist of first person deixis to identify the speaker, second person deixis used to appoint the addressee, and third person deixis refer to a person neither the speaker nor the addressee. Spatial deixis used to explain the location of certain utterance. Temporary deixis have function to describe an exact time of utterance. There are 676 deixis found in chapter one of the novel, consist of 569 person deixis, 85 spatial deixis, and 22 temporal deixis. By apprehending the deixis, people could avoid misunderstanding, avoid confusion, and gain more information.
\end{abstract}

Keywords: Linguistics, Pragmatics, Semantics, Deixis

\section{INTRODUCTION}

Language consists of word, symbol, number, body language, or even art. People often express something with language through diary, song, poetry, novel, film, painting, craft, etc. However language also has aesthetic side. The result of producing language can be found in form of speech, book, song, painting, and movie. Sometimes, the language in novel, poetry, and song often use pragmatic language. In pragmatic language, people have to know the meaning of reference word or known as deixis to understand about the whole context.

As stated in Weissenborn and Klein natural language is always used in certain situations - at a certain time and at a certain place by people who share a great deal of both situational perception and general knowledge. this contextual boundness determines to a large extent how utterances in natural language are produced and comprehended. An utterance like "I told her that yesterday, when she was here" is fully understandable only if we are able to identify

(a) the speaker - the word "I" itself doesn't tell us who performed the action - (b) the time of utterance - otherwise, we wouldn't know when "yesterday" was-

(c) where this sentence was uttered - because "here" can be anywhere -

(d) who "I" was speaking to - the utterance says only that it is a female person ("her"), she ") and

(e) a part of what said before - namely what is taken up by "that".

In general, we don't have any problem in interpreting utterance of this kind, since all necessary information is provided either by the non-linguistic context --- (a), (b), and (c) may be derived from situation ---, or by the linguistic context --- (d) and (e) may be gathered from what has been said before. A speaker who plans his utterance can take it for granted that the listener has access to his contextual information, and this clearly affects the way in which the utterance is produced - what is made fully explicit, and what is left to the context.

They also stated contextuality is not only one of the most fundamental characteristics of natural languages - in contrast to formal languages; it is also one of the central links between language, perception, and cognition: what is meant when 
something is uttered depends on the linguistic form of the utterance, on features of the situation as perceived by speaker and listener (including previous utterances), and on general knowledge shared by them.

Deixis is interesting topic but unfortunately just a few people learn about it because it is rarely heard or known in daily life. Most people do not know about deixis because it looks unimportant, but it can be said that deixis is one of the important things in pragmatic in order to get to know the meaning of utterance of author's writing. Deixis can be found in language form of writing and speaking, even in your story that you tell to your friend. If there is wrong meaning of deixis, there will be wrong in understanding.

There are three types of deixis, they are person deixis, place deixis, and time deixis. In order to learn more about the deixis, the types of deixis and the meaning of deixis, the writers uses novel as the object to analyse the deixis. In daily life people read novel in their spare time, so it will be easy to understand by a reader. Novel usually tells story about our daily life such as romance, horror, action, mystery, and family. In novel sometimes there will be misunderstanding between the writers and the reader's perception. In order to prevent error and to understand easily, the writers chooses to analyse deixis used in a novel.

Girl in Pieces novel by Kathleen Glasglow is a novel about a seventeen years old girl, named Charlotte Davis who lost her father and her mother. The journey of her life was begun when she became vulnerable and lost her mind for a while. Charlie had to live in treatment center, even though she still had two brothers. Charlie struggled with her life and tries to build her life again.

Context is when reference is made only, or predominantly, to the non-linguistic situation in which an utterance is made from who is addressing whom, whether formally or informally, why, when, where, etc, for what purpose, we speak of the context of situation (Weiner, 2014:96). It means context is reference from the utterance made from the speaker and the listener, the reason, the purpose, time, place of the conversation. It could be said that context is situation of the communication.

Certain contexts may favour a particular speech act, e.g. when conditions for the offering of condolences exist, but the speech act of condoling is what a speaker does within the situation (Allan \& Nodoushan, 2015:4). It means context sometimes using gesture depend on the situation. For example when someone sad, people just hug them. Without a word, it could be another way of saying it is going to be fine in the end.

The various example of context is ranging from retail, tourism and banking to dating, weight loss and social media. (Cummins, et al, 2014:182). It means that context comes from informal situation and formal situation.

In context, a speaker may intend to use her words to represent particular representations, or sorts of representations, of the person to whom she's ascribing belief (Richard, 2013:22). It means that in context, the speaker takes a full control of words her when describing something to someone in particular representation ascribing belief.

Based on the whole theories above, it can be concluded that context is essential. It also mean as circumstances, purpose, topic, and person. Slightly context is also a symbol or gesture. It could be in form of informal or formal conversation that depends on the utterance.

Deixis is one of the branches in pragmatics. Deixis is word that reference to another word. Even though deixis only refer to another word, deixis is also very important to understand the meaning of a whole sentence or story.

While according to Yule in Abdullah (2015:4), deixis is one of the most fundamental elements we discuss in the perspective of contextual interpretation of an utterance. It means that in contextual interpretation of utterance, deixis is essential because one single mistake could be ruining the whole message. Bühler added that deixis is pointing out a relation of some sort personal, temporal, locational, etc. that holds between the speaker and the situation (Ajimer \& Rühlemann, 2015:332). It means deixis is pointing that involves person, time, and location between the speaker and the situation.

\section{According to Levinson S. C.}

Deixis is an important field studied in pragmatics, semantics and linguistics. Deixis refers to the phenomenon wherein understanding the meaning of certain words and phrases in an utterance requires contextual information. Words or phrases that require contextual information to convey any meaning are deictic; and furthermore Deixis concerns the ways in which languages encode ... features of the context of utterance ... and thus also concerns ways in which the interpretation of utterance/es depends on the analysis of that context of utterance. (Dylgjeri, 2013:87-88). 
It means that deixis is can be included in pragmatics, semantics, and linguistics. Deixis refers to some another words or something else to understand the meaning of specific words and phrase in an utterance based on the context. The words or phrases that need the context to convey the meaning are deictic.

Deictic is a word that has a pointing function that is used in deixis. While deixis is the use of certain linguistic items to refer to entities by pointing at them linguistically instead of providing information about their type, size, colour and so on. (Brown \& Miller, 2013:25). It means deictic is the word and a part of deixis, sometimes deictic expression could be called as deixis. Deictic expression is also known as indexical, while deixis is linguistic topic that refers an object by pointing at them linguistically instead of giving information about the object. For example "that guy is well-groomed" instead of "the handsome shiny hair guy in black suit is well-groomed".

Based on the explanation above, it can be conclude that deixis is branch of pragmatics which along with semantic. Deixis is point or reference some words meaning in contextual of utterance. It concern about who is the speaker, the time or place of speaking, and the current location in the discourse. Deixis might be indicated through physically e.g., pointing in direction, words here or there, gesture point at someone, and language e.g. pronouns I, You, this, that, here, there, etc.

Yule in Abdullah (2015:5) discusses the following three main types of deixis; person deixis, spatial deixis, and temporal deixis.

\section{Person Deixis}

According to Fillmore in Ivanova (2016:333) Person deixis is "the identity of the interlocutors in a communication situation". It means that person deixis is deixis that point out to a person. The person in here could be the speaker, the listener or the addressee, and the other person. In the perspective of person deixis I, you, he. Yule furnishes the concept of deixis tripartite system: speaker is I, addressee is you, and other is he, she, it. According to Levinson in Pratiwi (2018:41), there are three types of person deixis.

a. $\quad$ First person (I/We). The first person deixis is a reference that refers to the speaker or both speaker and referent grouped with the speaker which is expressed in singular pronouns such as I, me, myself, mine and plural pronouns such as we, us, ourselves, our, ours.

b. Second person (You). The second person deixis is a deictic reference to a person or people identified as addressee, such as you, yourself, yourselves, your, yours.

c. Third person (He, She, It, They). Third person deixis is a deictic reference to referens not identified as the speaker or addressee and usually imply to the gender that the utterance refers to, for example: he, she, they, him, himself, her, and herself.

Table 1.

The Pattern of Word in Person Deixis

\begin{tabular}{lll}
\hline Person & Singular & Plural \\
\hline $\mathbf{1}^{\text {st }}$ Person & I/Me & We/Us \\
\hline $\mathbf{2}^{\text {nd }}$ Person & You & You \\
\hline $\mathbf{3}^{\text {rd }}$ Person & He/Him, She/Her, It & They/Them
\end{tabular}

\section{Spatial Deixis}

Spatial deixis is deixis that point out to a place. Levinson says that, the expression of place deixis requires contextual information about the place of the utterance (Pangaribuan, Manik, \& Pasaribu, 2015:173). Examples of spatial deixis from modern English are: here, there; come, go; bring, take; this, that etc. Yule differentiated with two basic terms: proximal which is near speaker for example this, here, now and distal which is a way from speaker i.e. that, there, then.

\section{Temporal Deixis}

Simpson stated that temporal or time deixis, "concerns the ways in which the time of the events referred to in an utterance (reference time - mine) interacts with the time of the utterance itself (encoding time - mine)" (Ivanova, 2016:333). Temporal deixis is deixis that point out at time. In temporal deixis, linguistic expressions depend for their interpretation on knowing the relevant utterance time. Yule for instance, now: time coinciding with speaker utterance, then: past and future time relative to speaker's present time, yesterday, tomorrow, tonight, tomorrow, today: tense.

Novel is a piece of prose united as a book with genre fiction, romance, mystery, or daily life. People read novel when they need to relax but sometimes other people called them book nerd. In fact, reading novel also help us to gain knowledge. Kennedy stated that "a novel is a book-length story in prose, whose author tries to create the sense that, while we read, we experience actual life." (Desi Pratama, 2016:50). It means that novel is an actual 
imagination in real life created by the authors. It have a book length story, if it is short, it is not a novel.

According to Bronze in Desi Pratama (2016:50) stated "a novel is longer-often much longer- than a short story." It means that novel is longer than short story. Usually novel comes in a form of book but in this modern era, it will fit in your phone. Just buy the book online, it will go straight to your phone screen. It is getting easy to read novel anywhere without the consequence of heavily book.

While Watt in Maioli (2016:10) stated "that the novel is a full and authentic report of human experience, and is therefore under an obligation to satisfy its readers with such details of the story as the individuality of the actors concerned and the particulars of the times and places of their actions." It means that novel is an authentic story of human experience which is completed by individual character and particular times and place.

Novels register the silent changes that shape the possibilities of social interactions and form the earliest stirrings of the imagination, and they change as they capture the exquisite nuances that are the germs of the future (Wald \& Elliott, 2014:xix). It means that novels somehow manage to build social interaction with an encouragement of imagination. When catch the magnificent situation it change the plot of story which is the beginning of the future.

Based on the explanation above, the writers concludes that novel is story about human experience or imagination with the details of character, time, and place which have a booklength. While read novel, it could make us feel experience an actual life just like the story in the novel.

\section{METHOD OF RESEARCH}

This research was conducted by qualitative approach. Qualitative research is concerned with developing explanations of social phenomena. That is to say, it aims to help us to understand the social world in which we live and why things are the way they are. Therefore, the writers describe the topic they discussed based on the context of unusual terminology. The deixis that the writers describe was the interpretation of themselves as the researchers. As quoted by Duff, many - but certainly not all (e.g., Yin, 2003b) - qualitative researchers in the social sciences and humanities, especially in the $21^{\text {st }}$ century, believe that the same phenomenon or event may be viewed by the research participant, researcher, or another observer (relative, teacher, tester, employer).

Data have been taken naturally. As what is said by Ritchie, many of the methods used in qualitative research were developed to allow investigation of phenomena in their natural settings. They provide data which is an 'enactment' of social behaviour on its own social setting, rather than a 'recounting' of it generated specifically for the research study. They are of particular value where behaviours and interactions (whether acted, spoken or written) need to be understood in 'real world' contexts.

Referring to the research of the deixis used in Girl in Pieces novel by Kathleen Glasglow, the writers formulate the problem of their findings as follow: the types of deixis used and the meaning context of it, and the use of deixis affecting the context in reading.

\section{FINDING AND DISCUSSION}

The writers found five types of deixis in the novel but only three types of deixis that are going to categorize in this paper which are person deixis, spatial deixis, and temporal deixis. Person deixis is divided into sub types; first person, second person, and third person. While spatial deixis tends to lead a place whether it is far or near from the speaker according to context. Temporal deixis is point a time that could be past, present, and future time. Temporal deixis a little less found in the novel because the speaker usually says for present time. The meaning of deixis is very important in sentence. While the meaning of deixis could be a person, time, or place.

Below are the further explanation of deixis in the novel, after the writers categorized them in to three types; person deixis, spatial deixis, and temporal deixis according to Yule theories. It would be followed by the meaning of deixis in an utterance said by a speaker.

\section{Person Deixis}

Based on Levinson in Pratiwi (Pratiwi, 2018) Person deixis involves the identification of the participants. It means person deixis is an utterance that appoints a person. Person deixis divided in to three types, there are first person, second person, and third person.

\section{a. First Person}


First person deixis refers to the speaker herself. Sometimes the deixis of the first person could be I as singular and We as plural. The words that include as first person deixis according to Levinson in Pratiwi (2018:41) are I, Me, Myself, Mine, We, Us, Our, Ours, and Ourself. Those are the first person deixis used in the novel.

\section{Excerpt 1 (Page 11 paragraph 2)}

Louisa: "My problem, it gets in the way"

The utterance is said by Louisa. There was a first person deixis, 'My'. My referred to the speaker herself which is Louisa. It able to include in first person deixis because the word " $m y$ " is a possessive objective to something that belong to her as singular pronoun. While the meaning according the context, Louisa wants the listener to know that the problem is her nervousness. It blocks her way in music career to sing in a band that is why she did not sing in a band anymore.

\section{Excerpt 2 (Page 18 paragraph 3)}

Casper: "You just missed Easter at Creeley. You were a little out of it. You didn't miss much. We can't really have a giant bunny hopping around a psych ward, can we?"

The utterance is said by Dr.Stinson also known as Casper. There was first person deixis 'we'. The function of the word we is subject of plural pronoun. The word we referred to Casper, Charlie, the staff, and the girls at Creeley. According to context, Casper was answering Charlie question about how long she has been in Creeley center. Charlie has been in Creeley for six days since the middle of April. Actually, Charlie just missed Easter at Creeley but there is not so much going on. Even, they do not have giant bunny in treatment centre for psychic patient.

\section{Excerpt 3 (Page 24 paragraph 4)}

Barbero: "I get to be your teacher"

The utterance is said by Barbero. There was first person deixis 'I'. I referred to the speaker, Barbero. The word I have a function which is the subject as singular pronoun. The context is Jen S. was taking Charlie to Rec. room. Barbero was already in the room. The doctor in Creeley center thinks that Charlie needed a project. Therefore the good doctor asked Barbero to help Charlie in learning. It is just like back to school for Charlie. Barbero is going to be Charlie's teacher who checks her lesson and quizzes.

\section{Excerpt 4 (Page 34 paragraph 1)}

Louisa: "I need to tell you, you aren't the same as us, you know? Look around. These sheets, this bed, our meds, the doctors. Everything here speaks money. Are you listening?"

The utterance is said by Louisa. There was first person deixis 'our'. The function of the word is the object as plural pronoun. Our referred to Louisa and Charlie. While the meaning is Louisa said that Charlie is different from the other girls in Creeley. Everything is paid by family patient including the sheets, bed, meds, and the doctors. Because some patient is having mental issues from their family, in that case the girls sent off to treatment center otherwise the girls choose to stay in Creeley avoiding from people outside.

\section{Excerpt 5 (Page 43 paragraph 3)}

Charlie: "Nurse. Ava. Bought. Me. This. Underwear."

The utterance is said by Charlie. There was first person deixis 'me'. Me referred to the speaker herself, Charlie. The word me have a function as the subject of singular pronoun. The context was because Charlie thinks hurting herself was making her feel better but the problem is after, the scars. Nurse Vinnie took care of Charlie's scars on her skin. Charlie who was mute suddenly said to Nurse Vinnie that the pink underwear she had was bought by Nurse Ava.

\section{b. Second Person}

Second person deixis refers to the addressee of speaker. It is known as the You person. The form of deixis according to Yule in second person deixis are you, your, yourself, and yourselves. Those are the second person deixis used in the novel.

\section{Excerpt 1 (Page 3 paragraph 3)}

The security guard: "Holy Mother of God, girl, what's been done to you?"

The utterance is said by security guard of Region Hospital. There was second person deixis 'you'. It referred to the addressee in the utterance that is Charlie. It was on the lawn of Regions Hospital, Charlie was left alone. She was wrapped in a bed sheet with freezing sleet and snow. Then the security guard who found her smelled menthol cigarettes and the flat stink of machine coffee. So he saved her from freezing in a cold wet grass. 


\section{Excerpt 2 (Page 22 paragraph 2)}

Doc Dooley: "We had to take everything out, for your safety."

The utterance is said by Doc Dooley. There was second person deixis 'your'. It referred to Charlie's safety. The context was Doc Dooley gave Charlie her backpack but its empty. The green backpack which have a lot of her stuff such tender kit, socks, underwear, rolls of toilet paper, pills, canister film, sketchpad, pens, and Land camera. Doc Dolley emptied it for Charlie's safety because she might hurt herself with that stuff.

\section{Excerpt 3 (Page 34 paragraph 3)}

Louisa: "You need to prepare yourself, is all I'm saying."

The utterance is said by Louisa. There was second person deixis 'yourself'. The function of word yourself referred to Charlie. Louisa said that because she was talking about her life in Creeley. Louisa was thrown away by her family who paid for her fees to take rehabilitation in Creeley. It means Charlie have to prepare herself to face up with real world that everything is about money.

\section{Excerpt 4 (Page 51 paragraph 1)}

Casper: "Talking. Cutting your hair. Bandages off. How do you feel?"

The utterance is said by Casper. There was second person deixis 'your'. The function of the word your referred to Charlie's belonging which is her hair. The context was in individual session Casper talked to Charlie that she did big changes. Charlie who was mute just started talking, cutting her hair, and taking off her bandages that cover her scars. It is a good way to start new life.

\section{Excerpt 5 (Page 64 paragraph 1)}

Charlie: “ But he's part of why I did it. You know? Like, the straw and the camel. Everything. Do you understand?"

The utterance is said by Charlie. There was second person deixis 'you'. The word you referred to Evan. Evan was calling to check on Charlie. He asked the reason of Charlie's hurting herself. Evan remembered a long time ago there was an accident in Seed House. When he, Dump, Charlie, and Ellis entered the house, a man named Frank with bad intention whose came for Charlie. Frank did bad things to the girls that he met, and then the girls will disappear or a mess. Luckily, he did not get Charlie because she was hiding in the attic. Yet he is one of the reason why Charlie hurting herself.

\section{c. Third Person}

Third person deixis refers to someone else neither the speaker nor the addressee that could have a far or a near distance from the speaker. The words that are including as third person deixis according to Yule for example he, she, they, him, himself, her, herself, and it. Those are the third person deixis used in the novel.

\section{Excerpt 1 (Page 64 paragraph 1)}

Charlie: "No. No, he didn’t get me."

The utterance is said by Charlie. There was third person deixis 'he'. It referred to Frank. The function of the word he is the subject as singular pronoun. The context Charlie and Evan were talking about their dark old times. When Evan and Dump took Charlie to Seed House, there was a man named Frank with black eyes and hungry eyes. Every girl that came to Seed house and got in the room with red door always disappears after that. Charlie who hid in the attic did not get noticed by Frank. That is why Frank did not get Charlie.

\section{Excerpt 2 (Page 65 paragraph 4)}

Evan: "You know, that comic book you made. I don't know, I just like it. It's cool, you know, like, seeing me in there. Like I'm famous or something. I read a little every day.”

The utterance is said by Evan. There was third person deixis 'it'. The word it referred to comic book. The function of the word it is object as singular pronoun. Evan was telling Charlie that he took her comic book so he feels sorry. He took that comic book because he likes the drawing of himself in the book that made by Charlie. He feels famous, cool, and feels something so he is happy that he read it every day.

\section{Excerpt 3 (Page 66 paragraph 2)}

Charlie: "She's excellent."

The utterance is said by Charlie. There was third person deixis 'she'. The word she referred to Charlie's mom. The function of the word she is the subject of singular pronoun. While the context is there was a phone call for Charlie from her mother. When she talked on the phone, it turned out Evan who was pretend to be her mother. In that case, Charlie's friend who thought she got a phone call from her mother ask how her mother doing when 
the phone call over. Charlie could easily answer that her mother is excellent on vacation to Portland.

\section{Excerpt 4 (Page 72 paragraph 1)}

Teacher: "Charlotte, I know things are so hard right now,but they'll get better. Sometimes it takes a while to find that special friend, but you will. Oh, gosh, I don't think I had a really good-good friend until I was in high school."

The utterance is said by Charlie's teacher. There was third person deixis 'they'. They referred to the circumstances. The function of the word they is object as plural pronoun. When Charlie was elementary school student in fourth grade, she did not have a friend. There was a nice teacher who never yelled. She told Charlie that it is okay if you do not have a friend right now, it take time to find the special friend. Even though the circumstances are hard right now, it will be better. The teacher itself found her good friend in high school.

\section{Excerpt 5 (Page 78 paragraph 2)}

Casper: "Your mother's not working right now, so there isn't any possibility of coverage. As I understand it, some of your stay has been covered by your grandmother, but she's unable to continue due to her own health and financial care issues."

The utterance is said by Casper. There was third person deixis 'it'. The word it referred to the coverage of Charlie's stay. The function of the word it is the object as singular pronoun. Dr. Helen and Dr. Stinson told that Charlie was being discharged because she made strong strides in such a short time and there is not any possibility of coverage for her stay. Charlie's mother was not working and her grandmother who used to cover her stay could not continue due to health and financial issues.

\section{Spatial Deixis}

Spatial Deixis is deixis word refers to place whether it is near or far from the speaker according Yule (Pangaribuan et al., 2015:173). Example of spatial deixis according to Levinson are here, there; come, go; bring, take; this, that etc. While Yule proximal which is near speaker for example this, here, now and distal which is a way from speaker i.e. that, there, then. Those are the spatial deixis used in the novel.

\section{Excerpt 1 (Page 11 paragraph 1)}

Louisa: "I was the very first fucking girl here, back when they opened, for God's sake"
The utterance is said by Louisa. There was spatial deixis 'here'. The word here referred to Creeley Center. The function of the word here is adverb of place. The word 'here' is proximal terms because when Louisa said 'here', she was in Creeley center at that moment. Louisa explained to Charlie that she has been the first girl in Creeley when they opened a long time ago. She just likes the queen who never had planned to leave Creeley.

\section{Excerpt 2 (Page 22 paragraph 3)}

Doc Dooley: "But you can have these"

The utterance is said by Doc Dooley. There was spatial deixis 'these'. The word these referred to a photograph of Charlie, Ellis, Mikey, and Danny. The function of the word these is the object. The word 'these' is proximal terms because Doctor Dooley said it while giving square linen of Charlie and friends photograph. The context was Doctor Dooley was giving a green backpack to Charlie, her backpack. The backpack was empty, they emptied it. Doctor Dooley only gave Charlie a photograph for her to keep for her own safety.

\section{Excerpt 3 (Page 25 paragraph 1)}

Barbero: "the good doctor says you have to start taking meds at night to sleep and I have a feeling you don't wanna do that. She'd rather have you in here than creeping down the halls like you do. Because that's fucking weird"

The utterance is said by Barbero. There was spatial deixis 'that'. The word that referred to take medicines. The function of the word that is as an object. The word that is distal terms because that is taking medicine that happen every night before the girls going to bed.

\section{Excerpt 4 (Page 37 paragraph 5)}

Blue: "Tell everybody what you wrote on your paper, there, Silent Sue"

The utterance is said by Blue. There was spatial deixis 'there'. The word there referred to the paper. The function of the word there is object. The word there is distal terms because Blue asked Charlie to read what is written on a paper. It was a Group time, everyone has time to speak up their mind. But Charlie just wrote what is going in her mind on a piece of paper. It is written out. Get it out. Cut it all out and Blue accidentally saw the written on Charlie's paper.

Excerpt 5 (Page 45 paragraph 1) 
Nurse Vinnie: "You apply this twice a day. That shit's gonna itch real bad now that it's out in the air. Gonna feel tight and kinda prickly."

The utterance is said by Nurse Vinnie. There was spatial deixis 'this'. The word this referred to a cream. The function of the word this is object. The word this is proximal terms because Nurse Vinnie was talking while giving a cream to Charlie. The context was Nurse Vinnie took care of Charlie's scars that caused by hurting herself. After cleaning the scars, Nurse Vinnie was giving Charlie a cream for her scars to apply the cream twice a day. The cream was given to reduce her pain.

\section{Temporal Deixis}

Temporal Deixis is deixis word refers to time that the speaker mean in an utterance (Ivanova, 2016). The forms of temporal deixis are now, then, yesterday, tomorrow, today, tonight, next weeks, last weeks, and this weeks. Below there are temporal deixis used in the novel.

\section{Excerpt 1 (Page 47 paragraph 5)}

Nurse Vinnie: "Now. Has to be now."

The utterance is said by Nurse Vinnie. There was temporal deixis 'now'. The word now referred to right at the moment in present time. The function of the word now is explaining that the activity has to be done right now. The context was Charlie in a care room, it was time to take a good care of Charlie's appearance. Charlie washed her body, but still feels empty. She saw a picture of Nurse Vinnie with all the other girls, pretty hair, smiley face, and chubby cheeks. Nurse Vinnie saw that then decided to cut Charlie hair, even though she did not want to. Nurse Vinnie was going to cut her hair right now, it has to be at that time.

\section{Excerpt 2 (Page 78 paragraph 3)}

Dr. Helen: "There's a halfway house that may have room for you, possibly as early as next month. They specialize in substance addiction, but that is one of your subsets. You'll need to stay with your mother before then, of course, since you can't stay here. No one wants you back in your previous situation, no one."

The utterance is said by Dr.Helen. There was temporal deixis 'next month'. The word next month referred to a month after Charlie's release. The function of the word next month is adverb of time. The context, Charlie was being discharge but she have to live with her mother for a while until next month. Then she could live at the house on Palace that will be having a vacant room early next month. The Palace has specialized on substance addiction that will be her subset.

\section{Excerpt 3 (Page 79 paragraph 2)}

Charlie: "It's still cold outside."

The utterance is said by Charlie. There was temporal deixis 'cold'. The word cold referred to the weather. The function of the word cold is adverb of time. It is explain that the weather outside is cold because it's autumn. The context was Charlie was being discharge from Creeley. She will live with her mother again. She makes a reason that the weather outside is cold. When actually she just does not want to live with her mother who yelled at her, hit her, and broke her. She could not bear with all of those things anymore.

\section{Excerpt 4 (Page 85 paragraph 1)}

Mikey: "I told you I was coming! You were supposed to put me on a visitors' list or something. I'm only here for one more day. I'm here for the show later tonight and then we go in the morning."

The utterance is said by Mikey. There was temporal deixis 'in the morning'. In the morning referred to morning after which represent future time. The function of the word in the morning is adverb of time. It is explain that Mikey mad because he is not in the visitor list. Although Charlie was certain that she put Mikey name on the list. Mikey promised he was coming over, but he does not have plenty of time because he comes for the show tonight, and then they go in the morning.

\section{Excerpt 5 (Page 98 paragraph 4)}

Charlie's mom: "Your friend Mike came by late last night. We all know it's not gonna work out, you with me, or you in some freaking teen halfway house. That's not you, Charlotte. I don't know what is you, but I'm not it, and I'm pretty sure some curfew house isn't it. Mike's mom bought you a bus ticket to Arizona. You'll stay in his apartment down there. He says he'll help you."

The utterance is said by Charlie's mom. There was temporal deixis 'late last night'. Late last night referred to yesterday in the middle of the night. The function of the word late last night is adverb of time. Charlie's mother is explaining the relationship of Charlie and her mother is not going to work out, curfew house or even Charlie living at Palace. Yesterday in the middle of the night, Mikey came bring a bus ticket to Arizona which Mikey's mom bought it for Charlie because he have an apartment there and he will help her. 
Types of Deixis used in the Novel

a. Person Deixis

Table 2.

Data of Words as First Person Deixis

\begin{tabular}{clc}
\hline No. & Deixis & $\begin{array}{c}\text { Amount of } \\
\text { deixis }\end{array}$ \\
\hline 1 & I & 120 \\
\hline 2 & Me & 29 \\
\hline 3 & My & 21 \\
\hline 4 & we & 29 \\
\hline 5 & us & 4 \\
\hline 6 & Our & 3 \\
\hline 7 & Myself & 1 \\
\hline & Total & $\mathbf{2 0 7}$ \\
\hline
\end{tabular}

Based on the table of data above, the most first person deixis used is I refer to the speaker herself. Then, in the second place there is two deixis word $\mathrm{Me}$ and We. Me refers to speaker herself as singular pronoun and We refer to speaker as plural pronoun. The deixis word My is in the third place, followed by Us, Our, and Myself.

Table 3.

Data of Words as Second Person Deixis

\begin{tabular}{clc}
\hline No. & Deixis & Amount of deixis \\
\hline 1 & You & 194 \\
\hline 2 & Your & 41 \\
\hline 3 & Yours & 1 \\
\hline 4 & Yourself & 8 \\
\hline \multicolumn{2}{l}{ Total } \\
\hline
\end{tabular}

Based on the table of data above, the most second person deixis used is You refer to the addressee or to the listener. Then, in the second place there is deixis word Your. Your refers to possessive adjective. The deixis word Yourself is in the third place, followed by Yours.
Table 4.

Data of Words as Third Person Deixis

\begin{tabular}{clc}
\hline No. & Deixis & Amount of deixis \\
\hline 1 & He & 18 \\
\hline 2 & His & 2 \\
\hline 3 & Him & 3 \\
\hline 4 & She & 25 \\
\hline 5 & Her & 11 \\
\hline 6 & It & 37 \\
\hline 7 & Itself & 1 \\
\hline 8 & They & 18 \\
\hline 9 & them & 2 \\
\hline 10 & Their & 1 \\
\hline Total & $\mathbf{1 1 8}$ \\
\hline
\end{tabular}

Based on the table of data above, the most third person deixis used is It refer to someone or to something as singular pronoun. Then, in the second place there is deixis word She. She refers neither to the speaker nor the addressee. The deixis word He and They is in the third place, followed by Her, Him, His, Them, Itself, and Their.

\section{b. Spatial deixis}

Table 5.

Data of Words as Spatial Deixis

\begin{tabular}{clc}
\hline No. & Deixis & Amount of deixis \\
\hline 1 & Here & 25 \\
\hline 2 & There & 14 \\
\hline 3 & This & 17 \\
\hline 4 & That & 26 \\
\hline 5 & Those & 1 \\
\hline 6 & These & 2 \\
\hline \multicolumn{3}{r}{ Total } \\
\hline \multicolumn{3}{r}{} \\
\end{tabular}


Based on the table of data above, the most spatial deixis used is That refer a distal place which is far from the speaker. Then, in the second place there is deixis word Here. Here refers to proximal place which is near the speaker. The deixis word This is in the third place, followed by There, These, and Those.

\section{c. Temporal deixis}

Table 6.

Data of Words as Temporal Deixis

\begin{tabular}{clc}
\hline No. & \multicolumn{1}{c}{ Deixis } & Amount of deixis \\
\hline 1 & Now & 10 \\
\hline 2 & Night & 2 \\
\hline 3 & Last night & 1 \\
\hline 4 & Cold & 1 \\
\hline 5 & Next month & 1 \\
\hline 6 & Everyday & 1 \\
\hline 7 & One more day & 1 \\
\hline 8 & Later tonight & 2 \\
\hline 9 & In the morning & 1 \\
\hline 10 & a while ago & $\mathbf{2 2}$ \\
\hline 11 & Then & \\
\hline & Total & \\
\hline
\end{tabular}

Based on the table of data above, the most temporal deixis used is Now refer to present time. Then, in the second place there is deixis word Night and In the morning. Night is also present time because it is habitual, while in the morning is future time. The rest of deixis word in temporal deixis is Last night, Cold, Next month, Everyday, One more day, Later tonight, a while ago, and Then.

It can be conclude that in the total of 676 deixis, the person deixis as second person is the most types of deixis used in the novel with 244 deixis. The second is person deixis as first person with 207 deixis, and then the third is person deixis as third person with 118 deixis. Spatial deixis in fourth place with 85 deixis and the last is temporal deixis with 22 deixis. The deixis that being used by character are You and $I$ deictic as a pronoun of the speaker or the addressee.

\section{The Affect of Deixis in Reading the Novel}

After found deixis and analyzed the meaning of deixis in the novel, the writers is going to give an explanation of how deixis is affecting the context in a whole novel. There will be also a brief example how small word of deixis could affect a whole novel. The novel that is going to analysis is novel with a title Girl in Pieces written by Kathleen Glasglow. Deixis is contributing to a whole novel indirectly in affecting the understanding of the novel which compatible with author purposes.

Firstly, the affect of using deixis in novel could lead misunderstanding for some people. Even though deixis is rare topic but it is important to understand it. By understanding deixis, people could avoid misunderstanding in story that lead to a whole novel. It is not difficult to understand deixis, but it is not easy either. It can be seen in page 64 in novel when Charlie said 'he did not get me'. Charlie was on the phone with Evan, they talk about two people who are Dump and Frank. The reader who did not understand clearly could get the meaning wrong. They could guess that he was referred to Dump which is wrong. He was referred to Frank. Frank is a bad person in the novel but if the readers get it wrong, it could be Dump that is a bad person when he is not a bad person. That is why deixis is important. If people have a will to learn, people will be understanding deixis as a piece of cake.

Secondly, the reader should understand the deixis to avoid the confusion in reading the novel. The confusion of deixis in reading novel is normal. Confusion would be hard to avoid because the lack of deixis understanding. If the reader confused which word is refers to, the reader would not get the meaning. Then a reader will be confused about the whole story just because a reader missed one word meaning. For example, in page 22 when Doc Dooley said Charlie can have these to Charlie. Doc Dooley was holding a green backpack, tender kit, and a photograph. People would be confused what are these referred to. These were actually referred to a photograph. Because there is an explanation of the situation in the context before and after the utterance. So it is also matter to understand the context, beside understand the deixis.

Lastly, deixis can improve reading, listening, writing, and speaking skill of people in English. By learning and understanding deixis could be affecting people knowledge. It would be easier to get information clearly. The certain information could be checked in deixis and context. In that case it would be wasted to understand the meaning but far from the context. Then the purposes of the 
conversation would not deliver and there will be mistaken of message.

\section{CONCLUSION}

After the writers analyzing the data, the deixis used in the novel become clear. There is person deixis which is a word that referred to person or the addressee of the speaker. In person deixis there are three types, first person deixis, second person deixis, and third person deixis. First person deixis is a word that referred to the speaker itself. While second person deixis is a word that referred to the addressee of the speaker. Then third person deixis is a word that referred to someone else, neither the speaker nor the addressee. It could be someone far away or near the speaker. Spatial deixis is a word that point to a place which could be distal and proximal. Temporal deixis is a word that referred to a time which has a function as an adverb.

The meaning of each deixis is various based on the context in the novel. The meaning of person deixis is a person for certain but sometimes appoint to things. The spatial deixis appoint to place and object that could be distal or proximal. The temporal deixis is refer to time such as now, today, every day, in the morning, last night, tomorrow, etc. The meaning is also various based on the context of the story that character discussed about.

There are 676 deixis used in the novel. The types of deixis used in Girl in Pieces novel written by Kathleen Glasglow were; 569 person deixis, 85 spatial deixis, and 22 temporal deixis. The first in person deixis is second person deixis because the character said 'you' a lot that refer to the addressee. Then first person deixis, ' $I$ ' is the most deixis used in first person deixis refer to the speaker itself. Followed by third person deixis with with 'it' that refer to something else other than the speaker or the addressee. The spatial deixis is 'here' appoint to a place which is place of a speaker located. The last is temporal deixis, the most deixis word used is now referring to a time as right at moment when a speaker talked.

Deixis is only small part of pragmatic that is barely known by people. However it does not change the fact that it is matters. There will be misunderstanding and confusion. That is why people sometimes lacking to read because they do not understand one simple word meaning. Deixis is invisible for some people but the affecting of it is very big. One mistake in deixis could affect the meaning or message in story or even in a whole novel. Then some people decided to read again in order understanding the meaning of word in the context that affecting a whole story.

\section{REFERENCES}

Abdullah, M. (2015). Deixis: A Pragmatics Analysis. India: Language in India, 15(December 2015), 3-9.

Ajimer, K., \& Rühlemann, C. (2015). Corpus Pragmatics: A Handbook. Cambridge: Cambridge University Press.

Allan, K., \& Nodoushan, M. A. S. (2015). Pragmatics: The state of the art (An Online Interview with Keith Allan). Melbourne: International Journal of Language Studies, 9(3), 1-8.

Brown, K., \& Miller, J. (2013). The Cambridge Dictionary of Linguistics. Cambridge: Cambridge University Press.

Cummins, S., Peltier, J. W., Schibrowsky, J. A., \& Nill, A. (2014). Consumer behavior in the online context. West Yorkshire: Emerald Group Publishing Limited. Journal of Research in Interactive Marketing, 8 No.3(August), 169-202. https://doi.org/10.1108/JRIM-04-2013-0019

Desi Pratama, R. M. (2016). Dissociative Identity Disorder Of Main Character In Sybil Novel By Flora R. S Based On Psychological Perspective ISSN: 1979-4975 ISSN : 19794975. Jakarta: Progressive, XI(2), 49-58.

Dylgjeri, A. (2013). Deixis in Modern Linguistics and Outside. Elbasan: Academic Journal of Interdisciplinary Studies, 2(4), 87-96. https://doi.org/10.5901/ajis.2012.v2n4p87

Ivanova, A. (2016). Deixis and its role in defining rhetorical space Deixis y su papel en la definición del espacio retórico. Chile: Revista Signos. Estudios De Linguistica ISSN 0718-0934, 49(92), 329-349. https://doi.org/10.4067/S071809342016000300004

Maioli, R. (2016). Empiricism And The Early Theory Of Novel. Distribution. Florida: Palgrave Macmillan.

Pangaribuan, R. E., Manik, S., \& Pasaribu, T. (2015). Deixis Used on Business Brochures Text: A Pragmatics Study. Medan: International Journal of English Linguistics, 5(5),

171-182. 
https://doi.org/10.5539/ijel.v5n5p171

Pratiwi, S. (2018). Person Deixis in English Translation of Summarized Shahih AlBukhari Hadith in the Book of. Medan: Advances in Language and Literary Studies ISSN: 2203-471, 9(1), 40-43.

Richard, M. (2013). Context and the Attitudes: Meaning in Context Volume 1 (First Edit). Oxford: Oxford University Press.

Wald, P., \& Elliott, M. A. (2014). The Oxford History of the Novel in English: The American Novel 1870 - 1940 (Volume 6). Oxford: Oxford University Press.

Weiner, E. (2014). The Oxford Dictionary of English Grammar (Second Edi). Oxford: Oxford University Press.

Wibowo, A. I., \& Naulfar, N. (2018). Deixis And Its Context Used In "Girl In Pieces" Novel By Kathleen Glasglow. Wanastra, 10(2), 73-84. 